\title{
A CONVENIENT METHOD FOR THE DETERMINATION OF MOISTURE IN AROMATIC PLANTS
}

\author{
Flávio A. Pimentel* \\ Departamento de Ciência dos Alimentos, Universidade Federal de Lavras, CP 37, 37200-000 Lavras - MG, \\ Embrapa Acre, CP 321, 69901-180 Rio Branco - AC \\ Maria das Graças Cardoso, Ana Paula S. P. Salgado, Priscila M. Aguiar e Vanisse de F. Silva \\ Departamento de Química, Universidade Federal de Lavras, CP 37, 37200-000 Lavras - MG \\ Augusto Ramalho de Morais \\ Departamento de Exatas, Universidade Federal de Lavras, CP 37, 37200-000 Lavras - MG \\ David Lee Nelson \\ Departamento de Alimentos, Faculdade de Farmácia, Universidade Federal de Minas Gerais, 31270-901 Belo Horizonte - MG
}

Recebido em 10/12/04; aceito em 15/8/05; publicado na web em 13/1/06

\begin{abstract}
A method is proposed for the determination of the moisture content of aromatic plants. This method is based on the co-distillation of the starting material in a modified Clevenger apparatus with four organic solvents (toluene, cyclohexane, dichloromethane and carbon tetrachloride). The results were compared with those obtained by oven drying at $105{ }^{\circ} \mathrm{C}$ and steam distillation of the essential oil. The efficiencies of the methods were shown to be equivalent. The solvent distillation method was more practical, especially with respect to operating time $(2 \mathrm{~h})$.
\end{abstract}

Keywords: aromatic plant; moisture content; essential oil.

\section{INTRODUCTION}

Among other chemical constituents, aromatic plants possess essential oils resulting from secondary metabolism. These substances have a great economic potential, especially in the food, pharmaceutical and perfumery sectors. Thus, the number of studies on the chemical composition and biological properties of these oils, as well as the taxonomic, environmental and cultivation factors that lead to variations in their quantity and quality, has been growing ${ }^{1}$.

The ISO (International Standard Organization) defines essential oils as the products obtained from parts of plants through steam distillation, as well as by pressing the pericarps of citric fruits. In general, they are composed of complex mixtures of volatile, lipophilic, liquid and odiferous substances. They may also be described as volatile oils, ethereal oils and essences ${ }^{1}$.

The research on active substances from plants in Brazil is still incipient. Until the beginning of the 1980's, it was estimated that the chemical composition of less than $1 \%$ of the species of Brazilian flora was known ${ }^{2}$. Even considering that significant increments in the knowledge of Brazilian flora have occurred in the last two decades, there is still a large gap to be filled ${ }^{3}$. On the other hand, the results of published research on essential oils have revealed little with respect to the methods utilized, leaving doubts as to the values obtained. Among the parameters evaluated, the determination of the moisture content of the starting material is of fundamental importance for the comparison of the various treatments on a dry basis. One method utilizing xylene for the determination of humidity in aromatic plants has been recommended ${ }^{4}$. The use of ovens at temperatures above $35{ }^{\circ} \mathrm{C}$ for this purpose would mask the results since there may be loss of essential oils in addition to the moisture at this temperature. Considering the above mentioned problems, the present work discusses the development of a method for

*e-mail: flavio.pimentel@globo.com determining the moisture content in aromatic plants utilizing different organic solvents with the aim of attending the scientific community as well as others interested in this area.

\section{EXPERIMENTAL PART}

The starting material consisted of fresh leaves from the Cymbogon nardus, Cymbopocum citratus, Thymus vulgaris, Piper aduncum, Piper hispidinervum, Menta aryensis and Menta villosa species cultivated in the Medicinal Plants Garden of the Federal University of Lavras. The studies were performed in the autumn during the period from April to June, when the average temperature varied from 17.3 to $20.6{ }^{\circ} \mathrm{C}$. Ten grams of chopped leaves from each species were submerged in $125 \mathrm{~mL}$ of each of the solvents toluene, cyclohexane, carbon tetrachloride and dichloromethane. The respective mixtures were placed in distillation flask $(500 \mathrm{~mL})$ coupled to a modified Clevenger apparatus. The flasks were heated at $100 \pm$ $5{ }^{\circ} \mathrm{C}$ with heating mantles. The distillates containing two phases (aqueous and organic) were collected in graduated glass tubes and the volumes of the aqueous phases were measured. The calculation of the moisture content was based on a $100 \mathrm{~g}$ sample. The experiment was conducted in a completely randomized delineation with three repetitions and the treatments were arranged in a 3 by 4 factorial scheme constituted by the factors distillation time (1,2 and $3 \mathrm{~h})$ and solvents (toluene, cyclohexane, carbon tetrachloride and dichloromethane), the toluene being considered as a control for the other solvents. The choice of this solvent was based on the AOAC Official Method, Da 2b-42, for the determination of moisture in products containing volatile substances ${ }^{5}$. The comparative analyses of all the solvents occurred separately relative to the control. That is, one sample was distilled with cyclohexane and with toluene. A second sample was distilled with dichloromethane and with toluene and a third sample with carbon tetrachloride and toluene. Each repetition of the analyses was performed in duplicate.

To determine the efficiency of the control in the detection of 
the moisture content, the moisture content was determined by drying in an oven at $105^{\circ} \mathrm{C}^{6}$, while the essential oil content was determined by steam distillation using a modified Clevenger apparatus ${ }^{7,8}$. To extract the essential oil, $100 \mathrm{~g}$ of fresh leaves from each species was chopped and transferred to a distillation flask (1 L) containing water. The extraction was performed for four hours at constant temperature. The distillate was centrifuged to separate the phases, and the volume and density of the essential oil were measured.

The two procedures (oven and essential oil) were performed simultaneously. The quantity of essential oil extracted from each starting material was deducted from the loss in weight obtained by the oven method to calculate the moisture content. The yields of the essential oils were determined for the dry weights of the samples whose moisture contents were determined by the solvent and oven methods.

\section{RESULTS AND DISCUSSION}

After one hour of distillation, significant differences in the determination of the moisture contents relative to the control were only observed for dichloromethane and carbon tetrachloride for the Menta arvensis e Menta villosa species. After two hours of distillation, no differences in moisture contents relative to the control were observed, although the values were higher than those observed during the first hour of distillation.

The control and the distillation with cyclohexane were the treatments that presented the greatest efficiency in terms of distillation duration. A significant difference between the first and succeeding hours was observed for the control in the treatments of only one species (Piper hispidinervum); for cyclohexane in the treatment of two species (Cymbogon nardus and Menta villosa); for carbon tetrachloride with Cymbogon nardus, Piper aduncum, Menta arvensis and Menta villosa; and for dichloromethane with Piper aduncum, Menta arvensis and Menta villosa (Tables 1 to 7).

Table 1. Average moisture contents (\%) of fresh leaves of Cymbogon nardus as a function of the types of solvents used during each distillation period

\begin{tabular}{lccc}
\hline Solvents & \multicolumn{3}{c}{ Time (h) } \\
\cline { 2 - 4 } & $1^{*}$ & $2^{*}$ & $3^{*}$ \\
\hline Cyclohexane & $55^{\mathrm{aA}}$ & $69^{\mathrm{bB}}$ & $69^{\mathrm{bB}}$ \\
Toluene & $63^{\mathrm{aA}}$ & $68^{\mathrm{bA}}$ & $68^{\mathrm{bA}}$ \\
Carbon Tetrachloride & $57^{\mathrm{aA}}$ & $66^{\mathrm{abB}}$ & $65^{\mathrm{abB}}$ \\
Toluene & $63^{\mathrm{aA}}$ & $67^{\mathrm{bA}}$ & $63^{\mathrm{abA}}$ \\
Dichloromethane & $53^{\mathrm{aA}}$ & $57^{\mathrm{aA}}$ & $58^{\mathrm{aA}}$ \\
Toluene & $58^{\mathrm{aA}}$ & $63^{\mathrm{abA}}$ & $61^{\mathrm{abA}}$ \\
\hline
\end{tabular}

*Averages in the same column followed by the same lower case letter do not differ at $5 \%$ of probability by the Tukey test; averages in the same row followed by the same upper case letter do not differ. $\mathrm{CV}(\%)=6.32$; Overall average $=62.37$

With the exception of Piper hispidinervum, the essential oils obtained all had densities lower than that of water $(0.48-0.96 \mathrm{~g} /$ $\mathrm{cm}^{3}$ ). The yields of the essential oils on a dry weight basis, using the oven and toluene distillation methods, had very low differences $(0.01-0.09 \%)$, as was also the case for the moisture contents $(0.24$ $-1.27 \%$; Table 8$)$.

Although the methods tested gave very similar results for the moisture contents of aromatic plants, the use of solvents was more efficient in terms of operational time. The determination of moisture content by the solvent method was performed in two hours, while at least 24 hours are necessary using the oven method. In addition, the oven method requires a separate determination of the yield of essential oil for the calculation of the moisture content. The fact
Table 2. Average moisture contents (\%) of fresh leaves of Cymbopocum citratus as a function of the types of solvents used during each distillation period

\begin{tabular}{lccc}
\hline Solvents & \multicolumn{3}{c}{ Time (h) } \\
\cline { 2 - 4 } & $1^{*}$ & $2^{*}$ & $3^{*}$ \\
\hline Cyclohexane & $66^{\mathrm{aA}}$ & $69^{\mathrm{aA}}$ & $69^{\mathrm{aA}}$ \\
Toluene & $66^{\mathrm{aA}}$ & $70^{\mathrm{aA}}$ & $70^{\mathrm{aA}}$ \\
Carbon Tetrachloride & $64^{\mathrm{aA}}$ & $68^{\mathrm{aA}}$ & $68^{\mathrm{aA}}$ \\
Toluene & $66^{\mathrm{aA}}$ & $70^{\mathrm{aA}}$ & $70^{\mathrm{aA}}$ \\
Dichloromethane & $63^{\mathrm{aA}}$ & $69^{\mathrm{aA}}$ & $69^{\mathrm{aA}}$ \\
Toluene & $66^{\mathrm{aA}}$ & $70^{\mathrm{aA}}$ & $70^{\mathrm{aA}}$ \\
\hline
\end{tabular}

*Averages in the same column followed by the same lower case letter do not differ at $5 \%$ of probability by the Tukey test; averages in the same row followed by the same upper case letter do not differ. CV $(\%)=5.74$; Overall average $=67.96$.

Table 3. Average moisture contents (\%) of fresh leaves of Thymus vulgaris as a function of the types of solvents used during each distillation period

\begin{tabular}{lccc}
\hline Solvents & \multicolumn{3}{c}{ Time $(\mathrm{h})$} \\
\cline { 2 - 4 } & $1^{*}$ & $2^{*}$ & $3^{*}$ \\
\hline Cyclohexane & $47^{\mathrm{aA}}$ & $53^{\mathrm{aA}}$ & $53^{\mathrm{aA}}$ \\
Toluene & $50^{\mathrm{aA}}$ & $54^{\mathrm{aA}}$ & $54^{\mathrm{aA}}$ \\
Carbon Tetrachloride & $45^{\mathrm{aA}}$ & $52^{\mathrm{aA}}$ & $52^{\mathrm{aA}}$ \\
Toluene & $50^{\mathrm{aA}}$ & $54^{\mathrm{aA}}$ & $54^{\mathrm{aA}}$ \\
Dichloromethane & $45^{\mathrm{aA}}$ & $50^{\mathrm{aA}}$ & $50^{\mathrm{aA}}$ \\
Toluene & $50^{\mathrm{aA}}$ & $54^{\mathrm{aA}}$ & $54^{\mathrm{aA}}$ \\
\hline
\end{tabular}

*Averages in the same column followed by the same lower case letter do not differ at $5 \%$ of probability by the Tukey test; averages in the same row followed by the same upper case letter do not differ. CV $(\%)=11.05$; Overall average $=51.24$.

Table 4. Average moisture contents (\%) of fresh leaves of Piper aduncum as a function of the types of solvents used during each distillation period

\begin{tabular}{lccc}
\hline Solvents & \multicolumn{3}{c}{ Time $(\mathrm{h})$} \\
\cline { 2 - 4 } & $1^{*}$ & $2^{*}$ & $3^{*}$ \\
\hline Cyclohexane & $69^{\mathrm{abA}}$ & $75^{\mathrm{aA}}$ & $75^{\mathrm{aA}}$ \\
Toluene & $68^{\mathrm{abA}}$ & $73^{\mathrm{aA}}$ & $74^{\mathrm{aA}}$ \\
Carbon Tetrachloride & $65^{\mathrm{abA}}$ & $74^{\mathrm{aB}}$ & $75^{\mathrm{aB}}$ \\
Toluene & $72^{\mathrm{bA}}$ & $76^{\mathrm{aA}}$ & $77^{\mathrm{aA}}$ \\
Dichloromethane & $60^{\mathrm{aA}}$ & $74^{\mathrm{aB}}$ & $74^{\mathrm{aB}}$ \\
Toluene & $69^{\mathrm{abA}}$ & $75^{\mathrm{aA}}$ & $76^{\mathrm{aA}}$ \\
\hline
\end{tabular}

*Averages in the same column followed by the same lower case letter do not differ at $5 \%$ of probability by the Tukey test; averages in the same row followed by the same upper case letter do not differ. CV $(\%)=5.21$; Overall average $=72.19$.

Table 5. Average moisture contents (\%) of fresh leaves of Piper hispidinervum as a function of the types of solvents used during each distillation period

\begin{tabular}{lccc}
\hline Solvents & \multicolumn{3}{c}{ Time $(\mathrm{h})$} \\
\cline { 2 - 4 } & $1^{*}$ & $2^{*}$ & $3^{*}$ \\
\hline Cyclohexane & $62^{\mathrm{bA}}$ & $64^{\mathrm{a}} \mathrm{A}$ & $64^{\mathrm{aA}}$ \\
Toluene & $63^{\mathrm{bA}}$ & $65^{\mathrm{aA}}$ & $65^{\mathrm{aA}}$ \\
Carbon Tetrachloride & $67^{\mathrm{bA}}$ & $71^{\mathrm{aA}}$ & $71^{\mathrm{aA}}$ \\
Toluene & $65^{\mathrm{bA}}$ & $70^{\mathrm{aA}}$ & $70^{\mathrm{aA}}$ \\
Dichloromethane & $46^{\mathrm{aA}}$ & $66^{\mathrm{aB}}$ & $66^{\mathrm{aB}}$ \\
Toluene & $53^{\mathrm{aA}}$ & $68^{\mathrm{aB}}$ & $68^{\mathrm{aB}}$
\end{tabular}

*Averages in the same column followed by the same lower case letter do not differ at $5 \%$ of probability by the Tukey test; averages in the same row followed by the same upper case letter do not differ. CV $(\%)=5.67$; Overall average $=64.80$. 
Table 6. Average moisture contents (\%) of fresh leaves of Menta arvensis as a function of the types of solvents used during each distillation period

\begin{tabular}{lccc}
\hline Solvents & \multicolumn{3}{c}{ Time $(\mathrm{h})$} \\
\cline { 2 - 4 } & $1^{*}$ & $2^{*}$ & $3^{*}$ \\
\hline Cyclohexane & $70^{\mathrm{bA}}$ & $73^{\mathrm{aA}}$ & $73^{\mathrm{aA}}$ \\
Toluene & $72^{\mathrm{bA}}$ & $74^{\mathrm{aA}}$ & $74^{\mathrm{aA}}$ \\
Carbon Tetrachloride & $65^{\mathrm{aA}}$ & $72^{\mathrm{aB}}$ & $73^{\mathrm{aB}}$ \\
Toluene & $72^{\mathrm{bA}}$ & $74^{\mathrm{aA}}$ & $74^{\mathrm{aA}}$ \\
Dichloromethane & $61^{\mathrm{aA}}$ & $71^{\mathrm{aB}}$ & $71^{\mathrm{aB}}$ \\
Toluene & $72^{\mathrm{bA}}$ & $74^{\mathrm{aA}}$ & $74^{\mathrm{aA}}$ \\
\hline
\end{tabular}

*Averages in the same column followed by the same lower case letter do not differ at $5 \%$ of probability by the Tukey test; averages in the same row followed by the same upper case letter do not differ. CV $(\%)=4.57$; Overall average $=72.06$.
Table 7. Average moisture contents (\%) of fresh leaves of Menta villosa as a function of the types of solvents used during each distillation period

\begin{tabular}{lccc}
\hline Solvents & \multicolumn{3}{c}{ Time (h) } \\
\cline { 2 - 4 } & $1^{*}$ & $2^{*}$ & $3^{*}$ \\
\hline Cyclohexane & $73^{\mathrm{bA}}$ & $80^{\mathrm{aB}}$ & $80^{\mathrm{aB}}$ \\
Toluene & $77^{\mathrm{bA}}$ & $81^{\mathrm{aA}}$ & $81^{\mathrm{aA}}$ \\
Carbon Tetrachloride & $65^{\mathrm{aA}}$ & $78^{\mathrm{aB}}$ & $78^{\mathrm{aB}}$ \\
Toluene & $77^{\mathrm{bA}}$ & $81^{\mathrm{aA}}$ & $81^{\mathrm{aA}}$ \\
Dichloromethane & $65^{\mathrm{aA}}$ & $76^{\mathrm{aB}}$ & $76^{\mathrm{aB}}$ \\
Toluene & $77^{\mathrm{bA}}$ & $81^{\mathrm{aA}}$ & $81^{\mathrm{aA}}$ \\
\hline
\end{tabular}

*Averages in the same column followed by the same lower case letter do not differ at $5 \%$ of probability by the Tukey test; averages in the same row followed by the same upper case letter do not differ. CV $(\%)=4.57$; Overall average $=72.06$.

Table 8. Average results for the analyses of moisture and essential oil contents of fresh leaves from seven aromatic plant species

\begin{tabular}{lccccc}
\hline Species & \multicolumn{3}{c}{ Determinations } \\
\cline { 2 - 6 } & $\begin{array}{c}\text { Density } \\
\left(\mathrm{g} / \mathrm{cm}^{3}\right)\end{array}$ & $\begin{array}{c}\text { Essential oil } \\
\text { MFB/OM }(\%)\end{array}$ & $\begin{array}{c}\text { Essential oil } \\
\text { MFB/TM }(\%)\end{array}$ & $\begin{array}{c}\text { Moisture } \\
\text { OM }(\%)\end{array}$ & $\begin{array}{c}\text { Moisture } \\
\text { TM }(\%)\end{array}$ \\
\hline C. nardus & 0.73 & 2.48 & 2.50 & 59.69 & 60.00 \\
C. citratus & 0.56 & 2.47 & 2.56 & 73.62 & 74.61 \\
T. vulgaris & 0.52 & 0.71 & 0.72 & 65.02 & 65.26 \\
P. aduncum & 0.96 & 1.28 & 1.32 & 71.97 & 72.15 \\
P. hispidinervum & 1.05 & 3.57 & 3.66 & 78.27 & 77.00 \\
M. arvensis & 0.54 & 1.61 & 0.52 & 82.27 & 81.00 \\
M. villosa & 0.48 & 0.73 & 0.68 & & \\
\hline
\end{tabular}

$\mathrm{MFB}=$ Moisture Free Basis; $\mathrm{OM}=$ Oven Method; $\mathrm{TM}=$ Toluene Method

that four different solvents with different degrees of toxicity were efficient in the determination of the moisture contents signifies that the methods may be very widely applicable.

\section{CONCLUSIONS}

The oven and toluene methods were equally efficient in the determination of the yields of essential oils and moisture. For the determination of the moisture content by the solvent method, the use of dichloromethane, cyclohexane, carbon tetrachloride and toluene are recommended. A preliminary test to define the ideal distillation period for the part of the plant to be studied is recommended.

\section{ACKNOWLEDGMENTS}

The EMBRAPA Acre and the Conselho Nacional de Desenvolvimento Científico e Tecnológico $(\mathrm{CNPq})$ for financial assistance and for doctorate and research fellowships.

\section{REFERENCES}

1. Simões, C. M. O.; Schenkel, E. P.; Gosmann, G.; Mello, J. C. P.; Mentz, L. A.; Petrovick, P. R.; Farmacognosia da planta ao medicamento, $5^{\mathrm{a}}$ ed., UFRGS/UFSC: Porto Alegre/Florianópolis, 2003.

2. Gottlieb, O. R.; Mors, W. B.; J. Agric. Food Chem. 1980, 28, 96.

3. Shapiro, J. P.; Arch. Insect Biochem. Physiol. 1991, 17, 191.

4. Jacobs, M.; The Chemical Analysis of Foods and Food Products, $3^{\text {rd }}$ ed., van Nostrand Reinhold Co.: New York, 1958.

5. AOCS Official Method Da2b-42.; Official Methods and Recommended Practices of the American Oil Chemists Society, $4^{\text {th }}$ ed., American Oil Chemists Society: Champaign, 1994.

6. Instituto Adolfo Lutz; Normas analíticas do Instituto Adolfo Lutz, $3^{\mathrm{a}}$ ed., Débora D. Estrella Rebocho: São Paulo, 1985.

7. Craveiro, A. A.; Fernandes, A.G.; Andrade, C. H. S.; Matos, F. J. de A.; Alencar, J. W.; Machado, M. I. L.; Óleos essenciais de plantas do Nordeste, $1^{a}$ ed., UFC: Fortaleza, 1981.

8. Shan, Y. K. V.; Dissertação de Mestrado, Universidade Federal de Lavras, Brasil, 2002. 